\title{
Insects Associated With Tea and Their Identification at Ntri (Shinkiari) Mansehra, Pakistan
}

\author{
Hamid Ullah (Corresponding author) \\ M. Phil, Department of Animal sciences, Quiad-i-Azam University, Islamabad,Pakistan \\ Tel: 92-034-6906-1403Ｅ-mail: hamiddirwi@gmail.com \\ Ibrar Muhammad \\ M. Phil, Department of Animal sciences, Quaid-i-Azam University, Islamabad, Pakistan \\ Tel: $923078404061 \quad$ E-mail: ibrarqau2013@gmail.com
}

Waheed Ullah

M. Phil, Department of Animal sciences, Quaid-i-Azam University, Islamabad, Pakistan

E-mail: waheedqau63@yahoo.com

Dr. Farzana Perveen (Supervisor)

Assistant Professor, Department of Zoology, SBBU, Sheringal KP, Pakistan

Tel: 92-944-885-529 E-mail: farzana_san@hotmail.com

Sohail Aslam

M.Phil Zoology. Scientific Officer in National Tea research institute, Manshera, Pakistan Tel: 92-333-784-0668Ｅ-mail: Sohailaslamch@gmail.com

Received: March 5, 2014 Accepted: March 20, 2014

doi:10.5296/jbls.v5i2.5233 URL: http://dx.doi.org/10.5296/jbls.v5i2.5233

\begin{abstract}
Tea plants are visited by different types of insects including tea pests and pollinator. The objective of the study was to identify tea associated insects in National Tea Research Institute (NTRI), Mansehra, Pakistan during April-June 2012.

A collection of tea associated insects was made during April-June 2012 in Tea Experimental Garden (TEG), NTRI, Mansehra, Pakistan. A total of 128 samples were collected from TEG
\end{abstract}


randomly.

During the present research, 10 species were identified. Species collected were brush-footed butterfly, Argynnis hyperbius (Linnaeus, 1763); painted lady, Vanessa cardui (Linnaeus, 1758), Lucerne butterfly, Colias electo (Linnaeus, 1763)( Nymphalidae); small cabbage white butterfly, Pieris rapae (Linnaeus, 1758), white cabbage butterfly, Pieris brassicae (Linnaeus, 1758)( Pieridae); Asiatic honey bee, Apis cerana Fabricius, 1793, Western honey bee, Apis mellifera Linnaeus, 1758(Apidae); seven-spot ladybird Coccinella septempunctata (Linnaeus, 1758)( Coccinellidae); blue marsh hawk Orthetrum glaucum (Brauer, 1865), Crimson-tailed marsh hawk, Orthetrum pruinosum neglectum (Rambur, 1842)( Libellulidae). Different numbers of individuals were collected of each species. Seventeen individuals of $P$. brassicae, 16 of C. septempunctata, 15 of P. rapae, 14 of C. electo, 13 of V. cardui and A. cerana, 10 of $A$. mellifera, 9 of $O$. pruinosum neglectum and 7 of $O$. glaucum.

It is concluded that there is a diversity to explain tea associated insects in NTRI, Mansehra, Pakistan.

Keywords: Apidae, Coccinellidae, Libellulidae, Mites, Nymphalidae, Pests, Pieridae

\section{Introduction}

History of tea growing countries shows that after plantation of tea crop within 8-10 yeas some pest/insects come up due to which crop yield affect badly. A number of approaches have been adopted by entomologists to gain knowledge of natural enemies of insects (Takagi, 1973).

The tea plant is attacked by several injurious insects, as the faggot-worm, Enmete Carmerii Linnaeus, 1844 one of the bagworms, whose larva carries a case made up of fragments of twigs and feeds upon leaves of the plant. The tea borer, Zeuzere coffete Nietner, 1861 is the larva of a cossid moth; it bores into the stems of both coffee and tea plants. Three species of bark-slice, Aspidiotus thew Linnaeus 1841; Aspidiotus flaccscens Nietner, 1863 and Aspidiotus transparens Linnaeus, 1832 also occur commonly upon tea, and the first named is one of the most serious enemies of the growing plant, very noticeable at the time of pruning. Three mites feed upon the leaves. One of them a red spider, Tetranychus bimaculatus Harvey, 1891 another five-legged tea mite, Typhlodromus eariatlas Harvey, 1895 closely related to the rust-mite of the orange. It feeds upon the lower leaves. The yellow tea mite, Acarus transluccns Nienter, 1859 feeds upon the buds and produces the condition called 'sulky'.In the world there are, 1031 arthropod species associated with tea; a small number of pests (about 3\%) are common throughout the world. As a result of autochthonous and heterochthonous recruitment and the influence of climate, altitude, nature of cultivation, and age of plantation, however, each geographic region may have its own distinctive pest complex (Chen and Chen, 1989).

The flowers are pollinated by insects. Tea is virtually self-sterile and almost entirely cross-pollinated. Supplementary pollination produced more, larger, and heavier capsules, better viability, and a higher grade of seed. Bees are the chief pollinating agents of tea (Bakhtadze, 1932). Syrphid flies, such as hoverflies and drone flies, are important non-selective pollinators. Various midges and thripes are comparatively minor opportunist pollinators. Ants also pollinate some kinds of flowers, but for the most part they are parasites. 
Some Diptera (flies) may be the main pollinators in higher elevations of mountains. Other insect orders are rarely pollinators (e.g.,Hemiptera such as Anthocoridae, Miridae) Jim et al., 2002. Keeping in view the importance of tea associated insects, the present studies were conducted to enlist these insects in National Tea Research Institute (NTRI), Mansehra, Pakistan.

\subsection{Study Area}

The insects were collected from all Experimental Tea Gardens (ETG) associated with NTRI, District Mansehra of Pakistan.

Mansehra is the North Eastern District of Khyber Pukhtunkhwa and at altitude of 975.36 meters (3200 feet). It is located between $34^{\circ}-14^{\prime}$ and $35^{\circ}-11^{\prime}$ north latitudes and $72^{\circ}-49^{\prime}$ ' and $74^{\circ}-08^{\prime}$ east longitude. The Nanga Parbat Mountain is located about 40 kilometers from the north eastern boundary of the district. Climate of the district is warm in summer and cold in winter. Temperature ranges from $2{ }^{\circ} \mathrm{C}-36^{\circ} \mathrm{C}$ in the district (Ali, 2005). Our Objectives were: 1) enlist tea associate insects in NTRI, at district Mansehra, 2) Create awareness regarding tea associated insects and their importance.

\section{Material and Methods}

The study was conducted during April-June, 2012 in Experimental Tea Garden (ETG), National Tea Research Institute (NTRI), Mansehra, Khyber Pakhtunkhwa, Pakistan and the following strategy were adopted for exploring species diversity and elaborating distribution of the tea associated insects at the study area.

\subsection{Collection and Preservation}

Insects associated with tea were collected from ETG, NTRI randomly by using aerial nets and naked hands, after killing them in chloroform bottle collected specimens were first placed on white thermo-foil by stretching their wings and antennae and a white paper was placed on their wings of each specimen to keep them smooth. These were pinned properly and leaved for few days in such condition to keep them dry and fixed. On drying these were properly labeled and mounted in the collection boxes. Naphthalene balls were placed in the boxes to keep them safe from the pests.

\subsection{Identification and Description}

For identification, the specimens were examined under stereoscope. Identification was done up to the specific level with the help of available literature. Help was also taken by already identified specimens placed in National Insects Museum NIM, National Agriculture Research Center NARC, Islamabad and NTRI, Mansehra. Valid names along with synonyms, habitat and distribution were given for the species already recorded from Pakistan. All the identified specimens were deposited in the Zoological Museum, Department of Zoology, Hazara University, Mansehra, Pakistan.

\subsection{Morphometry and Photography}

Identified specimens were subjected for measurement of their total body length and wingspan 
by using Digital Fractional Caliper (No. 147 UPC 01470, Toronto, Canada). Different number of specimens of each 10 identified species was measured. The specimens were placed one by one on top of a blank white sheet of computer paper for taking their photographs by using digital camera (14.1 mega pixel lenses, Sony Cyber-Shot DSC-W610, Tokyo, Japan). The photography was done of preserved specimens.

\subsection{Data Analysis}

The data were analyzed by MS Excel by using mean and standard deviation.

\section{Results}

During the present research, total of 128 samples were collected from Tea Experimental Garden (TEG), randomly and 10 species of 4 orders, Lepidoptera, Hymenoptera, Coleoptera and Odonata were identified. Different number of individuals was collected of each species. Seventeen individuals of $P$. brassicae, 16 of $C$. septempunctata, 15 of $P$. rapae, 14 of C. electo, 13 of $V$. cardui and A. cerana, 10 of A. mellifera, 9 of $O$. pruinosum neglectum and 7 of $O$. glaucum (Table 1).

Table 1. Tea associated insects identified during April-June 2012 in National Tea Research Institute (NTRI), Mansehra, Pakistan.

\begin{tabular}{|l|l|l|l|}
\hline Order & Family & Species & Number of individuals \\
\hline Lepidoptera & Nymphalidae & Argynnis hyperbius & 14 \\
\hline & & Vanessa cardui & 13 \\
\hline & Pieridae & Pieris brassicae & 17 \\
\hline & & Pieris rapae & 15 \\
\hline & & Colias electo & 14 \\
\hline & & Apis cerana & 13 \\
\hline Coleoptera & Coccinellidae & Coccinella septempunctata & 10 \\
\hline Odonata & Libellulidae & Orthetrum glaucum & 16 \\
\hline & & Orthetrum pruinosum neglectum & 09 \\
\hline Total & & & 128 \\
\hline
\end{tabular}

*Total number of individuals of species

Table 2. Morphometry of Body length and wing span of different Tea associated insects species collected during April-June 2012 in National Tea Research Institute (NTRI), Mansehra, Pakistan.

\begin{tabular}{|l|l|l|l|l|l|}
\hline SNo & \multicolumn{1}{|c|}{ Comman name } & Name of species & $\mathrm{N}^{*}$ & $\begin{array}{l}\text { Body Length } \\
(\mathrm{M} \pm \text { SD; } \text { mm })^{*}\end{array}$ & $\begin{array}{c}\text { Wing span } \\
(\mathrm{M} \pm \text { SD })\end{array}$ \\
\hline 01 & Brush-footed butterfly & Argynnis hyperbius & 11 & $20.64 \pm 0.48$ & $75.41 \pm 0.59$ \\
\hline 02 & Painted lady & Vanessa cardui & 09 & $17.79 \pm 0.35$ & $59.85 \pm 0.23$ \\
\hline 03 & White cabbage butterfly & Pieris brassicae & 13 & $19.57 \pm 0.39$ & $69.45 \pm 0.38$ \\
\hline 04 & Small cabbage white butterfly & Pieris rapae & 10 & $18.50 \pm 0.17$ & $58.68 \pm 0.29$ \\
\hline 05 & Lucerne butterfly & Colias electo & 09 & $15.57 \pm 0.35$ & $44.43 \pm 0.36$ \\
\hline 06 & Asiatic honey bee & Apis cerana & 08 & $11.95 \pm 0.22$ & $18.33 \pm 0.22$ \\
\hline 07 & Western honey bee & Apis mellifera & 07 & $11.69 \pm 0.31$ & $18.37 \pm 0.24$ \\
\hline 08 & Seven-spot ladybird & Coccinella septempunctata & 12 & $8.99 \pm 0.17$ & $11.41 \pm 0.23$ \\
\hline 09 & Blue marsh hawk & Orthetrum glaucum & 07 & $32.69 \pm 0.15$ & $52.66 \pm 0.17$ \\
\hline
\end{tabular}


\begin{tabular}{|l|l}
\hline 10 & Crimson-tailed marsh hawk
\end{tabular}

Orthetrum pruinosum neglectum

$70.43 \pm 0.22$

*Values are represented as mean \pm standard deviation. Mean with in a column followed by standard deviation, $\mathrm{N}^{*}=$ number of species examined for morphometry.

During the present research, species of four order were identified in which the order Lepidoptera consist of five species greater than the other orders, then order hymenoptera consist of two species, order Odonata consist of two species and the order Coleoptera consist of only one specie which is less than the other orders (Figure 1). All identified species were different population. The most populated species was $P$. brassicae and less populated is $O$. glaucum. Different species were different body length and wing span. Argynnis hyperbius have the largest wing span and Coccinella septempunctatathe smallest wing span, similarly Orthetrum pruinosum neglectum have the greatest body length and C. septempunctata have the smallest body length.

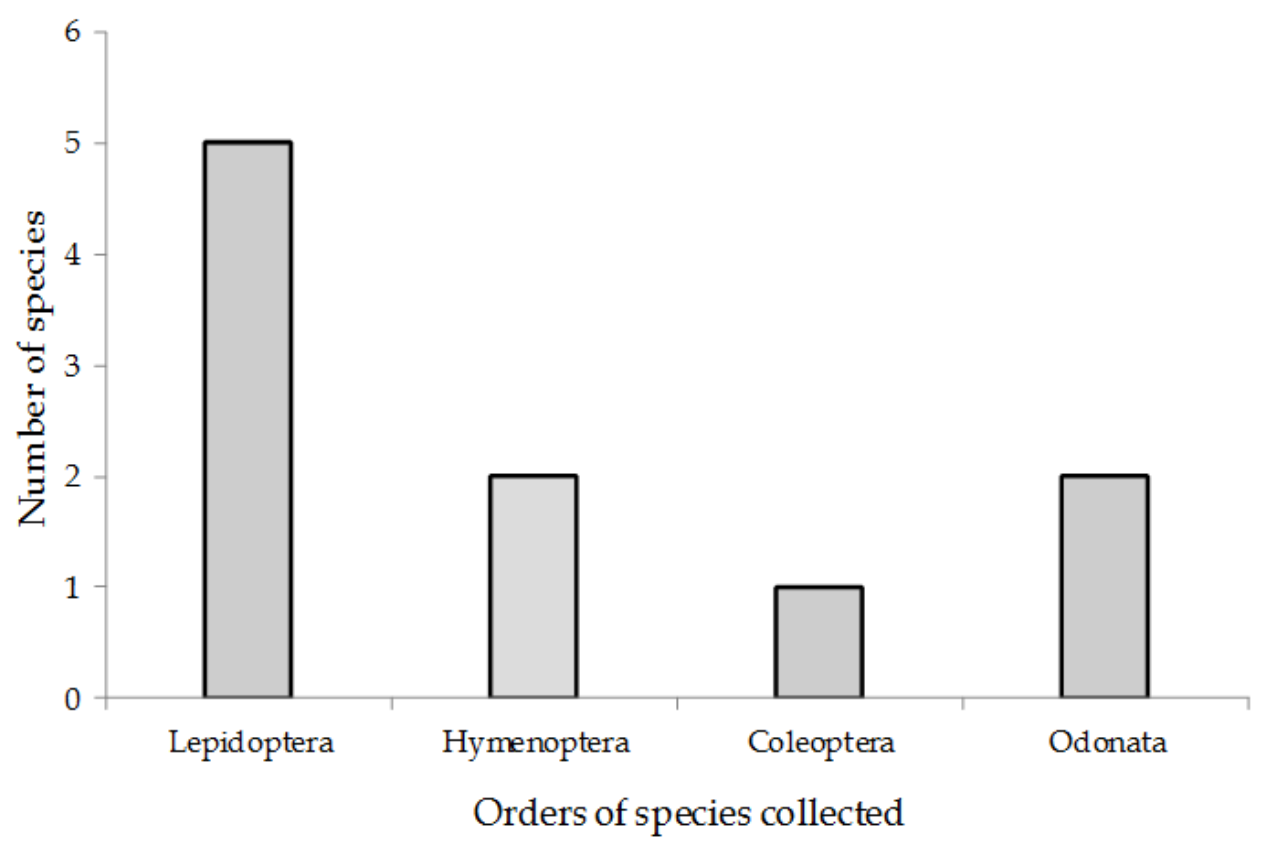

Figure 1. Population of insects associated with different insects orders were identified on tea, Camellia sinensis Linneaus, 1753 during April-June 2012 in National Tea Research Institute (NTRI), Mansehra, Pakistan.

\section{Discussion}

The present research was conducted in ETG, NTRI during which different butterfly fauna were documented. The study revealed that 5 species in 2 families and 4 genera occur in the area. The families include: Nymphalidae (generaArgynnisand Vanessa are represented); Pieridae (genera Pieris and Colias are represented). Abbas et al., 2002 were conducted a study in six different localities around Skardu to document the butterfly fauna of that region. The study revealed that 16 species in 5 families and 14 genera occur in the area. The families include: Papilionidae (represented only by the genus Parnassius); Pieridae (genera Pieris, Pontia and Colias are represented); Lycaenidae (genera Lycaena, Everes, Aricia, Plebejus, Zizeeria and Zizina are 
represented); Nymphalidae (only two genera, Aglais and Vanessa are represented); and Satyridae (represented by the genera Pararge and Maniola). Genus Pieris, Colias in family Pieridae and Vanessa in Nymphalidae were recorded in both the researches. Most of the genera were not found in the present study. Genus Argynnis was not reported in the previous research but recorded during present study. Differences were found due to climate difference. The previous research study area is harsh than the present research study region.

Only species Coccinella septempunctata Linnaeus, 1758 in family Coccinellidae and order Coleoptera was reported during the present research. Khan et al., 2006 were carried out an extensive survey of predatory Coccinellid beetles (Coleoptera: Coccinellidae) in the Chitral District, Pakistan. Twelve different species belonging to 9 genera of 3 tribes and 2 sub-families were recorded. Two sub-families, Coccinellinae and Chilocorinae were identified. The following 8 species belonged to family Coccinellinae and tribe Coccinellini, Coccinella septempunctata Linnaeus, 1758; Hippodamia variegata Goeze, 1777; Calvia punctata Mulsant, 1853; Adalia bipunctata Linnaeus, 1758; Adalia tetraspilota Hope, 1873; Aiolocaria hexaspilota Hope, 1873; Macroilleis hauseri Mader, 1930 and Oenopia conglobata Linnaeus, 1758. Only one species namely, Halyzia tschitscherini Semenov, 1807 represented tribe Psylloborini of the sub-family Coccinellinae. Three species occurred from sub-family Chilocorinae and tribe Chilocorini, Chilocorus rubidus Hope, 1807; Chilocorus circumdatus Gyllenhal, 1808 and Priscibrumus uropygialis Mulsant, 1853. From the aforementioned species 6 were recorded for the first time from Pakistan, Chilocorus circumdatus Gyllenhyl, 1808; Calvia punctata Mulsant, 1853; A. bipunctata; M. hauseri; P. uropygialis, and Oenopia conglobata Linnaeus, 1758. Coccinella septempunctata was documented from both the research study area. A large number of beetle fauna was not recorded in the present study as documented by previous research. Different host plants and climate are responsible for such huge differences.

Hamid et al., 1992 were conducted a study on insects associated with tea under natural conditions at Experimental Tea Garden, (ETG) Daively and National Tea Research Station, (NTRS) Shinkiari. Six tea varieties i.e., Qi-Men, Jue-Keng, Chuye, Ruopi and Huang-Shun (Chinese type) and High Grown (Sri Lankan) were included in the experiment. The insects observed feeding on tea were surface grasshopper, Acrotylus humbertianus Sauss, 1732; Chrotogonus trachypterus trachypterus Blanchard, 1741; Long horned grasshopper, Tettigonia cantans Fuessly, 1755; short horned grasshopper, Attractomorpha acutipennis Guer, 1777; rice grasshopper, Truxalis grandis Klug, 1722; Acrida exaltata Wlk Jassid, 1733; Amrasca devastans Distant, 1876 and aphid, Toxoptera aurantii Boyer, 1691. There was no similarity between both the researches. The climate and host plant both are the same but still no such species were documented during present study as recorded by previous research. The reason is the use of insecticides and pesticides during the present research work.

\section{Conclusions}

The present study was conducted pertaining to the biodiversity of tea associated insects in ETG, NTRI, Mansehra, Pakistan. During the present study species of 4 orders were reported. On the whole order Lepidoptera was dominant followed by Hymenoptera, Odonata and Coleoptera. Ruby et al., 2010 conducted studies pertaining to biodiversity of arthropods in the cropland of 
two zones i.e., mixed crop zone (Faisalabad) and Cotton-Wheat zone (Multan) Punjab, Pakistan for a period of one year. The main focus was to collect, identify and compare the species richness and evenness. Sugarcane, Fodder, Wheat and Brassica were sampled round the year showed variations in species composition of their fauna in the two districts representing the two zones. Mixed-crop zone was highly diversified with respect to species and abundance of individuals per species. On the whole order Orthoptera was dominant followed by Araneae, Hemiptera, Coleoptera, Lepidoptera, Hymenoptera, Odonata, Diptera and Thysanoptera, Neuroptera, Prostigmata each represented by single species except Mantodea with two species. All of the 4 orders which were recorded during the present research were also reported by the previous study. Some of the orders which were observed by the previous study were not reported during the present research. Dissimilarities in both the researches were due to the climate and host plant differences.

\section{References}

Abbas, M. Rafi, MA. Inayatullah, M. Khan, MR., \& Pavulaan, H. (2002). Taxonomy and distribution of butterflies (papilionoidea) of the Skardu region, Pakistan. The Taxanomic Report of the International Lepidoptera Survey. 3(9), 189-196.

Ahmad, N. Hamid, F S. Khan, AR., \& Waheed, A. (1992). Insects associated with tea at Mansehra (NWFP) Pakistan. Pakistan Journal of Agricultural Research. 13(4), 222-226.

Ali, I. (2005) Maping and documentation of cultural assests of Mansehra district, united National Scientific and Cultural Organization, Islamabad 1-91.

Bakhtadze, K. (1932). Pollination of tea, Camelia sinensis, in Georgia. Subtropics. 21(12), 63-80.

Chen, Z. Chen, X. (1989). An analysis of the world tea fauna. Journal of Tea Science. 9(15), $13-22$.

Jim, G. Mant, F. Schiestl, P. Rod, PP., \& Weston, H. (2002). A phylogenetic study of pollinator conservatism among sexually deceptive orchids. Evolution. 56(5), 888-898. http://dx.doi.org/10.1111/j.0014-3820.2002.tb01402.x

Khan, I. Din, S. Khalil, SK., \& Rafi, MA. (2006). Survey of predatory Coccinellids (Coleoptera: Coccinellidae) in the Chitral District, Pakistan. Journal of Insect Science. 7(7), 169-174.

Ruby, T. Akhtar, S. Rana, AM., \& Hameed, M. (2010). Biodiversity of Foliage Arthropods in the Mixed Crop Zone and Cotton-Wheat Zone in Punjab Province, Pakistan. International Journal of Agriculture and Biology. 12(6), 861-866.

Takagi, k. (1973). Monitoring of Hymenopterous parasite in tea field. National Research Institute of Tea, Japan. 10, 91-131.

\section{Copyright Disclaimer}

Copyright for this article is retained by the author(s), with first publication rights granted to the journal.

This is an open-access article distributed under the terms and conditions of the Creative Commons Attribution license (http://creativecommons.org/licenses/by/3.0/). 